Then in the War of 1914-18 came another change; at the crisis in 1917, when 'total war' was forced upon us and all peaceful activities had to be abandoned, Hall gave up the Development Commission and became Permanent Secretary to the Board of Agriculture under his old friend Prothero (afterwards Lord Ernle) as Minister. Here he was less happy than in his previous posts; he gave the impression that he found office routine very irksome; all his life he had been accustomed to prompt decision and speedy action, and in any event the times were unpropitious. When Bateson died in 1926 Hall accepted the directorship of the John Innes Horticultural Institution at Merton, retaining only a part-time connexion with the Ministry of Agriculture as its scientific adviser. Once more he was back in the atmosphere he loved; his coming, Darlington said, was like a breath of fresh air; and he rounded off a life-time of experience and observation of tulips and apples by producing two monographs which are not likely to be superseded in our time. He stayed on until 1939 and then retired, but only to change his occupation. He had always been interested in the Lord Wandsworth Agricultural School at Wantage, and as chairman of the governors he went to live there so that he might keep closer touch with its activities.

Few men can have lived a fuller life or one more helpful to the community. His influence will last long after our time, and the beneficial activities he started will go on bearing fruit, while his memory will be an abiding inspiration to all who had worked with him.

E. J. RusselL.

\section{Prof. D. la Cour}

Prof. Dan la Cour, director of the Meteorological Institute of Denmark, died at Copenhagen on May 19 at the age of sixty-five; his death will be deeply regretted by geophysicists throughout the world. During the past fifteen years or more he took an increasing part in international leadership in geophysics, the science for which above all others international co-operation is essential; at the time of his death he was president of the International Union for Geodesy and Geophysics. He was elected to this office at Edinburgh in 1936, and would normally have vacated it in 1939 , but at the Washington conference of the Union, held just after the outbreak of the present War, new elections of officers were postponed; his advice and guidance in re-starting the work of the Union when peace returns will be greatly missed.

Prof. la Cour was born at Copenhagen on September 12, 1876, of a family of high distinction in Denmark; his father was a High School physics master. After completing his university studies at Copenhagen, he became an assistant of the Meteorological Institute in 1900, under the directorship of van Ryd; in the year previous to this he took part in a Danish auroral expedition, and during 1900 he was leader of this expedition. From 1903 onwards he took charge of the Department of Weather Services, and from 1920 also of the Magnetic Department. In 1923 he became director of the Institute. From 1908 onwards he lectured on meteorology at the famous Copenhagen Polytechnic Institute. In 1927 he was elected to the Danish Academy of Sciences, and in 1939 to the Danish Academy of Technical Science. $\mathrm{He}$ received also many honours from other countries, and held numerous important offices in international scientific bodies.
Among the services la Cour rendered to the advancement of geophysical observation, one of the greatest was connected with the plans for the repetition, in 1932-33, of the International Polar Year of 1882-83, when the leading nations co-operated in sending expeditions to various parts of the north polar regions, in order to make meteorological, magnetic, auroral and other observations throughout a. whole year. The project for a renewal and extension of this work, with modern instruments and methods, in the jubilee of the original polar year, was mooted in good time for new expeditions to be planned, and in 1928 the International Meteorological Committee appointed a commission to organize the work. In 1931, however, the world economic crisis deepened, and there was danger of the project being abandoned; la Cour was foremost in withstanding this, and under his leadership, as president of the International Polar Year Commission, the great enterprise was carried through to success.

In facilitating afterwards the use of the large mass of new data thus obtained, la Cour likewise played an important part, with the enlightened generous support of the Danish Government. An international bureau was set up in his Institute, and there he organized the reproduction, on micro-films, of the magnetic and some other data. In this and his other work he and the skilled staff he gathered around him achieved first-rate results with great economy of money and effort.

$\mathrm{He}$ extended the scope of Danish observations in geomagnetism by establishing (in 1927) a permanent magnetic observatory at Godhavn, in Greenland (only $10^{\circ}$ from the pole of the earth's magnetic axis), in addition to the long-existing Copenhagen observatory (now at Rude Skov). He also started a new series of Danish geomagnetic publications ("Communications Magnétiques") to supplement the Danish magnetic observatory yearbooks.

La Cour also aided geomagnetic science very greatly by his many improvements in the design of magnetic instruments, through which the accuracy and reliability of magnetic observations and records were notably raised. He overcame several inveterate difficulties that long hindered the attainment of the high degree of precision aimed at in geomagnetic measurements. One such difficulty was connected with the use of fine quartz suspension fibres. The usual clamping of their ends did not prevent slipping, and injured the fibres : la Cour, who was himself an adept in their manipulation, left a quartz drop at each end of the fibre, and placed each drop in a simple mounting of special design; subsequent light heating fused the quartz and provided a safe connexion with the holder. Again, the magnetic balance, for the continuous measurement of the vertical magnetic force, is exceptionally sensitive to slight changes in the position of the magnet relative to the knife edges on which it is balanced; la cour avoided any such displacements by making the magnet, knife-edge and mirror in one piece, of tungsten steel, weighing in all only $2.5 \mathrm{gm}$. He also introduced a simple, ingenious and satisfactory method of optical temperature compensation for magnetic recorders. His improvements probably have valuable applica. tions in other branches of observational and experimental physics. Only a few of his instruments and devices are mentioned here; a paper describing the latest of his instruments, for the measurement of the vertical magnetic force, reached England only a few days ago. 
La Cour did much by example, precept and international intercourse to promote the improvement and extension of magnetic observations, and the intercomparison of magnetic standards. I was privileged in 1936 to accompany him on a tour with this object, to magnetic observatories and institutes in Sweden, Finland and Russia; he was a most kind, courteous and agreeable companion.

$\mathrm{He}$ was a tremendous worker, and was remarkable also for his capacity to inspire others with the same ardour, to an extent that perhaps sometimes surprised even themselves. His manner and his dignified movements suggested calm, irresistible strength.

La Cour was married and had one son and four daughters, who with Mrs. la Cour survive him. On his international journeys he was often accompanied by one or more members of his family, and in consequence there are many countries in which a personal sympathy with his family will be felt in their and our loss.
WE regret to announce the following deaths:

Prof. J. C. Arthur, emeritus professor of botany since 1915 at Purdue University, and president in 1902 and 1919 of the Botanical Society of America, known for his work on the plant rusts, on April 30, aged ninety-two.

Mr. F. C. Baker, curator emeritus of the Museum of Natural History of the University of Illinois, corresponding member of the Zoological Society of London, on May 7, at the age of seventy-four years.

Dr. G. B. Batten, a pioneer of X-ray treatment, who was president during 1918 of the Röntgen Society, on July 9, aged eighty-one.

Dr. Charles R. Keyes, consulting mining engineer, founder and editor of the Pan-American Geologist, on May 18, aged seventy-seven.

Dr. M. W. Lyon, jun., pathologist of the Clinic, South Bend, Indiana, and president during 1931-33 of the American Society of Mammologists, on May 19, aged sixty-seven.

\section{NEWS and VIEWS}

\section{Charles Blacker Vignoles and the Royal Society}

AT a meeting of the Royal Society on July 16, a gold snuff-box, once the property of Charles Blacker Vignoles, F.R.S. (1793-1875), was presented to the Society by his grandsons, Mr. E. B. Vignoles and Lieut.-Colonel W. A. Vignoles. Mr. Vignoles, in making the presentation, referred to the fact that in 1841 C. B. Vignoles presented to the Royal Society a fine portrait of Sir Isaac Newton, which had come to him as the result of a connexion between his mother's family and that of Sir Isaac. Mr. Vignoles said that his grandfather, who was of Huguenot descent, came of a long line of soldiers and was an orphan and a prisoner in French hands at the age of thirteen months. He was educated by his maternal grandfather, Dr. Charles Hutton, F.R.S., the mathematician, the author of "Hutton's Logarithms", in the preparation of which Vignoles assisted. As a young man he served for a time in the Army, taking part in the disastrous attack on Bergen-op-Zoom in 1814. Following the peace after Waterloo, he went to America, where he was engaged on survey work in South Carolina and Florida, then very little known. Returning to England in 1823 he was soon engaged in railway engineering, almost his first work being the first survey for the proposed Liverpool and Manchester Railway. In the course of a long career he carried out important work at home and abroad as a railway and civil engineer, including the great suspension bridge over the Dnieper at Kieff and a railway through the Cantabrian Pyrenees from Bilbao to Tudela, which with its sharp curves and bold moving of a river, struck a new note in railway engineering. The 'Vignoles rail', the flat-bottomed rail of his design still used all over the world, keeps his name familiar to railway engineers. Vignoles was elected a fellow of the Royal Society in 1855 and was president of the Institution of Civil Engineers in $1870-71$.

The snuff-box, now presented to the Royal Society, was given to Vignoles by the King of Württemburg, in 1844, as a mark of his esteem, after Vignoles had advised the King on plans for the railways of the State. The snuff-box is of solid gold with a portrait of the King set in diamonds on the lid; inside the lid is an inscription in French giving the circumstances of the presentation and signed by Goes, Secretary of State of Württemburg.

\section{Social Medicine at Oxford}

Thw Nuifield Provincial Hospitals 'Trust, with the approval of Lord Nuffield, is to devote $£ 10,000$ a year for ten years to the creation in the University of Oxford of a University professorship of social medicine, and the foundation of an institute in which the professor will work. The purposes of the institute are: "To investigate the influence of social, genetic, environmental, and domestic factors on the incidence of human disease and disability. To seek and promote measures, other than those usually employed in the practice of remedial medicine, for the protection of the individual and of the community against such forces as interfere with the full development and maintenance of man's mental and physical capacity. If required by the university to do so, to make provision in the institute for the instruction in Social Medicine of students and practitioners of medicine approved by the Board of the Faculty of Medicine in the University of Oxford."

\section{Scientific Men in War-time}

A deputation arranged by the Parliamentary and Scientific Committee saw Mr. R. A. Butler, president of the Board of Education and chairman of the War Cabinet Scientific Advisory Committee, who was accompanied by Prof. A. V.Hill, onJuly 16, to urge the Government to set up a full-time scientific and technical joint board. This would have as its aim the fullest strategic use of scientific man-power and resources and the proper organization and exchange of scientific and technical information relating to the war effort. The deputation included Lord Hinchingbrooke, Lord Leverhulme, Lord Pentland, Lord Samuel, Sir Lawrence Bragg, Capt. L. Plugge, Prof. B. W. Holman, Dr. W. Wooldridge, Mr. J. H. WoottonDavies, and representatives of the British Association of Chemists, Institute of Physics, Institute of Struo- 